\title{
ACTIVE UPTAKE OF DIHYDROMORPHINE AND OTHER NARCOTIC ANALGESICS BY CEREBRAL CORTICAL SLICES* ${ }^{*}$
}

\author{
J. T. Scrafani and C. C. Hug, JR. \\ Department of Pharmacology, University of Michigan Medical School, Ann Arbor, Mich., \\ U.S.A.
}

(Received 27 November 1967; accepted 1 March 1968)

\begin{abstract}
Narcotic analgesics have been shown to be accumulated in cerebral cortical slices by a process having the characteristics of an active transport system. In addition, diffusion and binding contributed to the total uptake of the analgesics into brain slices. The total uptake of dihydromorphine $\left(1 \times 10^{-6} \mathrm{M}\right.$ in medium) was found to reach steady state equilibrium in $30 \mathrm{~min}$ at $37^{\circ}$ with a maximum tissue to medium concentration ratio $(\mathrm{T} / \mathrm{M})$ of $2 \cdot 3$. Accumulation in vitro of the narcotic analgesics in brain differed from their accumulation in the kidney and in the choroid plexus in that there was a lower $\mathrm{T} / \mathrm{M}$ ratio at equilibrium for brain and the uptake by brain was not inhibited by quaternary organic bases. The narcotic analgesic antagonist, nalorphine, consistently depressed the uptake of dihydromorphine in a competitive manner.
\end{abstract}

NARCotic analgesics have been shown to be taken up by the kidney ${ }^{1-3}$ and choroid plexus $^{2}, 4$ by active transport processes. It has been suggested that transport of these drugs by the choroid plexus may facilitate their removal from cerebrospinal fluid, 2,4 just as their transport by the kidney promotes their elimination from the body.1,3

Upon administration of an analgesic dose, the central nervous system is the site of the most prominent effects of the narcotic analgesics. The central nervous system is known to have transport processes for the uptake and elimination of a variety of endogenous and exogenous substances. ${ }^{5,6}$ The transport systems are thought to affect the concentration of these substances in certain cellular and subcellular compartments. ${ }^{7}$ The present study was undertaken to determine if the narcotic analgesics interact with the transport systems of brain tissue. Such interaction could have significant implications for the distribution of these drugs in nervous tissue and for their pharmacological alteration of central nervous system function.

\section{MATERIALS AND METHODS}

Preparation of slices. Male Holtzman rats (150-200 g) were sacrificed by decapitation. The brain was removed, cut longitudinally into hemispheres and cerebral cortical slices $(10-40 \mathrm{mg})$ were cut freehand starting at the outer cortical surfaces by the method of Mcllwain and Rodnight. ${ }^{8}$ In order to avoid inclusion of white matter, only two slices were taken from each hemicortex of the rat; thus, in some experiments each

* A summary of the work presented in detail here appeared in The Pharmacologist 9, 218 (1967).

$\dagger$ This investigation was supported in part by Research Grant MH- 08580 from the National Institute of Mental Health. 
slice was divided into 2 equal parts in order to provide 8 slices from the same animal. As each slice was cut, it was floated in ice-cold medium.

In a few experiments cerebral cortical slices were prepared as described above from species other than the rat. Monkeys were anesthetized with diethyl ether, rabbits were sacrificed with i.v. air and mice by decapitation before removal of the brain.

Incubation of slices. Each slice was placed in $5 \mathrm{ml}$ of medium of the following composition (mM): $\mathrm{NaCl}, 134 ; \mathrm{KCl}, 2 \cdot 7 ; \mathrm{MgCl}_{2}, 0.48 ; \mathrm{CaCl}_{2}, 0.92 ; \mathrm{NaHCO}_{3}, 14 \cdot 8$; $\mathrm{Na}_{2} \mathrm{HPO}_{4}$ (adjusted to $\mathrm{pH} 7 \cdot 4$ with $\mathrm{HCl}$ ), 3.6; and glucose, 5.5. Before incubation a mixture of oxygen and carbon dioxide $(95: 5, \mathrm{v} / \mathrm{v})$ or of nitrogen and carbon dioxide $(95: 5, \mathrm{v} / \mathrm{v})$ was bubbled through the medium to adjust the $\mathrm{pH}$. Unless otherwise specified, all incubations were performed in a Dubnoff metabolic shaker at $37^{\circ}$ under a rapid flow of the gas mixture which always maintained the $\mathrm{pH}$ of the medium between $7 \cdot 3$ and $7 \cdot 5$.

All tissues were preincubated in medium for $15 \mathrm{~min}$. They were then transferred to fresh medium containing a radioactive narcotic analgesic with or without a potential transport inhibitor. When metabolic inhibitors were studied, they were added both to the preincubation medium and to the medium containing the narcotic analgesic. All other inhibitors were added as chloride salts only to the second medium. Uptake in the presence of an inhibitor was always compared to uptake without an inhibitor control by tissue from the same animal.

After incubation the tissue was removed from the incubation medium, blotted on glass, tightly wrapped in aluminium foil on dry ice and stored at $-10^{\circ}$ until it was weighed and analyzed within the succeeding $24 \mathrm{hr}$.

Analysis of radioactivity. The frozen tissues were weighed to the nearest microgram on a Cahn M-10 Electrobalance. They were then transferred to scintillation-grade glass vials and allowed to dry overnight in the open vials at room temperature. After drying, $3 \mathrm{ml}$ of $2 \mathrm{~N} \mathrm{KOH}$ in $95 \%$ ethanol were added to each vial to solubilize the tissue. The vials were tightly capped and placed in a covered, slowly oscillating shaker overnight at room temperature. Three $\mathrm{ml}$ of the $\mathrm{KOH}$-ethanol solution were added to 2 empty vials to serve as blanks. Care was taken to prevent contact of the solution with the aluminum liner of the vial cap, since considerable quenching was observed when alkali dissolution of the liner occurred. In addition, care was taken to avoid exposure of the solution to light, which turned the solution yellow. After dissolution of the tissue, $7 \mathrm{ml}$ toluene phosphor solution* were added to each vial and the vials were swirled carefully to mix the contents.

Duplicate $0 \cdot 2-\mathrm{ml}$ aliquots of the medium from each beaker (one slice per beaker) were pipetted into counting vials and $10 \mathrm{ml}$ of a $3: 7(\mathrm{v} / \mathrm{v})$ absolute ethanol : toluene phosphor solution were added.

Vials containing medium or tissue were then placed in a refrigerated liquid scintillation spectrometer (Packard Tri-Carb, model 3315) for $1 \mathrm{hr}$ prior to counting. This was done to bring the solution to $-4^{\circ}$ and also to eliminate any light activation of the glass which may have occurred.9 Quenching was determined by the use of a radioactive toluene internal standard. Background counts due to the usual sources and to

\footnotetext{
* Toluene phosphor solution was prepared by dissolving $3 \mathrm{~g}$ of 2,5 -diphenyloxazole (PPO) and $100 \mathrm{mg}$ of 1,4-bis-\{2-(4-methyl-5-phenyloxazolyl)\} benzene (Dimethyl POPOP, Packard Instrument Co.) in 1 liter of reagent grade toluene.
} 
the ${ }^{40} \mathrm{~K}$ present in the alkali-solubilized tissue were subtracted to give net counts per minute.

The results were expressed either as the concentration of narcotic analgesic per gram of tissue or per milliliter of medium or as the tissue to medium concentration ratio (T/M). Under Results, "per cent of control" refers to the uptake of the narcotic analgesic by a slice incubated in the presence of a potentially inhibitory compound compared to the uptake by a slice from the same animal incubated simultaneously in the absence of that inhibitor (control).

It should be noted that throughout this investigation, $5 \mathrm{ml}$ of medium were used for incubation of each slice of tissue (10-40 mg). The total amount of drug in the medium represented an excess such that the final concentration of the analgesic in the medium never differed from the initial concentration by more than 1 per cent. Total recovery of radioactivity from tissue and medium was equal to the quantity initially present in the medium.

Identification of dihydromorphine. Tissues were incubated exactly as described above for $90 \mathrm{~min}$ with either $10^{-3}$ or $10^{-6} \mathrm{M}$ dihydromorphine. Then, one-half of the tissue was homogenized in methanol and the other half in $0.01 \mathrm{~N} \mathrm{HCl}$. The homogenates were centrifuged at $1000 \mathrm{~g}$ for $10 \mathrm{~min}$. Both supernatants were concentrated under a stream of nitrogen at room temperature and then applied to Whatman No. 3 chromatography paper. The medium was also concentrated and applied to the paper. Nonradioactive dihydromorphine was applied to each paper as a standard. Descending chromatography was performed in the solvent systems given in Table 1.

TABle 1. Chromatographic analysis of RADioACtivity in CEREbral Cortical SLICES AND MEDIA AFTER INCUBATION FOR 90 MIN WITH $10^{-3}$ AND $10^{-6} \mathrm{M}$ DIHYDROMORPHINE- ${ }^{3} \mathrm{H}$

\begin{tabular}{|c|c|c|c|c|c|}
\hline \multirow{4}{*}{ Solvent system } & \multicolumn{5}{|c|}{$R_{f}$ Values* } \\
\hline & \multirow{3}{*}{$\begin{array}{l}\text { Nonradioactive } \\
\text { dihydromorphine } \\
\text { standard }\end{array}$} & \multicolumn{4}{|c|}{ Radioactive areas } \\
\hline & & \multicolumn{2}{|c|}{$10^{-3} \mathrm{M}$} & \multicolumn{2}{|c|}{$10^{-6} \mathrm{M}$} \\
\hline & & Tissue & Medium & Tissue & Medium \\
\hline 1. n-Butanol-glacial acetic & 0.58 & 0.58 & 0.59 & 0.55 & 0.56 \\
\hline $\begin{array}{l}\text { 2. tert-Amyl alcohol- } n \text {-butyl } \\
\text { ether-water ( } 80: 7: 13 \text {, v/v); } \\
\text { paper previously buffered to } \\
\text { pH } 8 \text { by dipping in } 0 \cdot 2 \mathrm{M} \\
\text { potassium phosphate }\end{array}$ & 0.77 & $0 \cdot 78$ & 0.70 & & \\
\hline $\begin{array}{l}\text { 3. n-Propanol-n-butanol- } 0 \cdot 1 \mathrm{~N} \\
\text { ammonium hydroxide }(2: 1: 1 \text {, } \\
\mathrm{v} / \mathrm{v})\end{array}$ & 0.83 & & & $0 \cdot 83$ & 0.87 \\
\hline
\end{tabular}

* See text for details.

Standards were located on the chromatogram under an ultraviolet light and by spraying with an iodoplatinate reagent. ${ }^{10}$ The chromatogram was scanned for radioactivity by cutting out the path of migration of the radioactive material and dividing it lengthwise into $1 \times 2 \mathrm{~cm}$ rectangles, each of which was placed at the bottom of a B.P.-F 
counting vial. One-half $\mathrm{ml}$ methanol was added to each vial to elute any radioactive material from the paper. After $10 \mathrm{~min}, 10 \mathrm{ml}$ toluene phosphor solution were added and the vials were swirled to mix the contents. Care was taken to see that the paper strips were lying flat at the bottom of the vials. The samples were counted and $R_{f}$ values were determined and compared to standards.

Each chromatogram contained a single peak of radioactivity with an $R_{f}$ value corresponding to that of standard dihydromorphine (Table 1), indicating that there was no metabolic alteration of dihydromorphine. If as little as 3 per cent of the radioactivity had been present as another compound, it should have been detected by this procedure.

Materials. Tritium-labeled dihydromorphine was prepared as described by Hug and Mellett ${ }^{11}$ and the sp. act. was adjusted to $20 \mathrm{mc} / \mathrm{m}$-mole by dilution with nonradioactive dihydromorphine. Levorphan $(0.9 \mathrm{mc} / \mathrm{m}-\mathrm{mole})$, dextrorphan $(1.7 \mathrm{mc} / \mathrm{m}$ mole), $d$-methorphan $(3.7 \mathrm{mc} / \mathrm{m}$-mole $)$ and $l$-methorphan $(0.6 \mathrm{mc} / \mathrm{m}$-mole $)$ were tritiated by New England Nuclear Corp. by the Wilzbach procedure and then purified in our laboratories. ${ }^{12}$ Tritium-labeled nalorphine $(1.1 \mathrm{mc} / \mathrm{m}$-mole) was prepared as described by Hug and Woods. ${ }^{13} \mathrm{~N}$-methyl-14 ${ }^{14}$-labeled morphine $(14.5 \mathrm{mc} / \mathrm{m}$-mole) was purchased from the Nuclear-Chicago Corp.

\section{RESULTS}

Uptake of dihydromorphine by rat cerebral cortical slices. The uptake of dihydromorphine $\left(1 \times 10^{-6} \mathrm{M}\right.$ in medium) by rat cerebral cortical slices was rapid initially and reached a maximum $(\mathrm{T} / \mathrm{M}=2.3 \pm 0.01)$ at $30 \mathrm{~min}$ (Fig. 1). Beyond $30 \mathrm{~min}$, an esscntially constant $\mathrm{T} / \mathrm{M}$ of $2 \cdot 1$ was found for incubation periods lasting up to $120 \mathrm{~min}$.

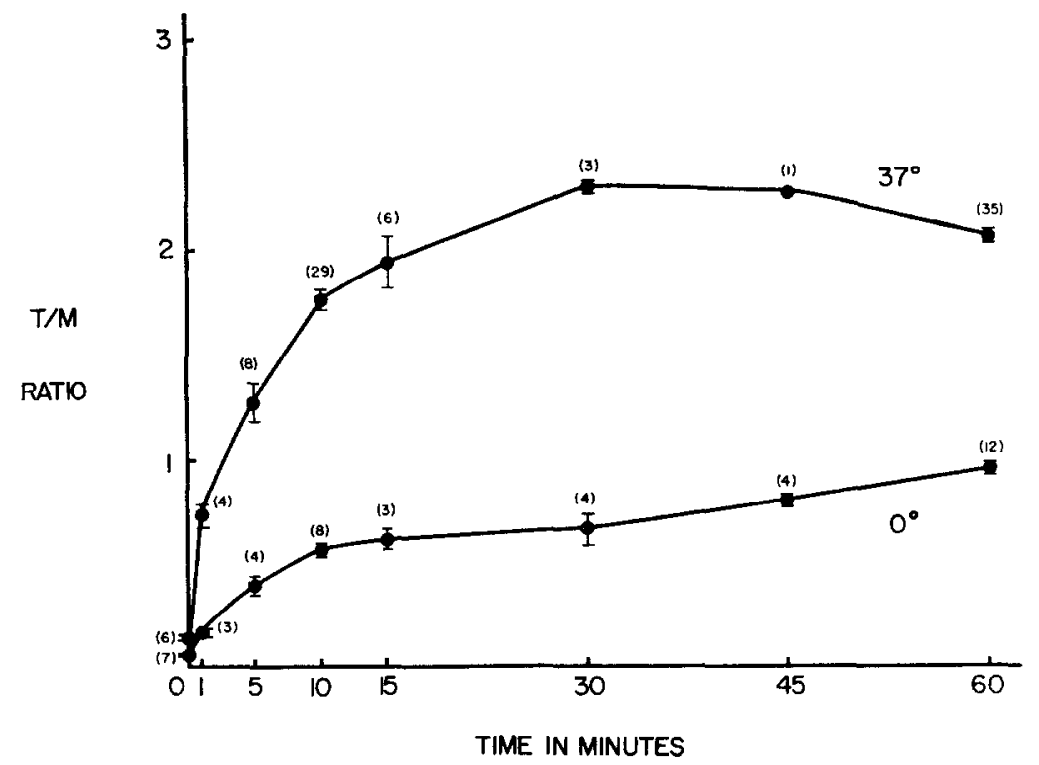

Fig. 1. Accumulation of dihydromorphine with time by cerebral cortical slices from rats. The slices were incubated in Krebs-Ringer bicarbonate medium containing $1 \times 10^{-6} \mathrm{M}$ dihydromorphine in an atmosphere of $\mathrm{O}_{2}: \mathrm{CO}_{2}(95: 5)$ at $37^{\circ}$. All tissues were preincubated for $15 \mathrm{~min}$ in medium without dihydromorphine. Brackets indicate \pm S.E.M. for the number of animals indicated in parentheses. 
At an incubation temperature of $0^{\circ}$, a constant tissue to medium concentration ratio $(T / M)$ of $0.92 \pm 0.04$ S.E.M. $(n=12)$ was found after $60 \mathrm{~min}$. This ratio approximates that expected for simple diffusion of dihydromorphine into total tissue water, which represents $85-90$ per cent of the tissue wetweight. ${ }^{14}$

The accumulation of dihydromorphine in tissue slices during $10 \mathrm{~min}$ of incubation at $37^{\circ}$ was dependent on the initial concentration of dihydromorphine in the medium (Fig. 2). The $\mathrm{T} / \mathrm{M}$ ratio declined with increasing concentrations of dihydromorphine up to $5 \times 10^{-6} \mathrm{M}$, suggesting that a portion of the uptake process was saturable.

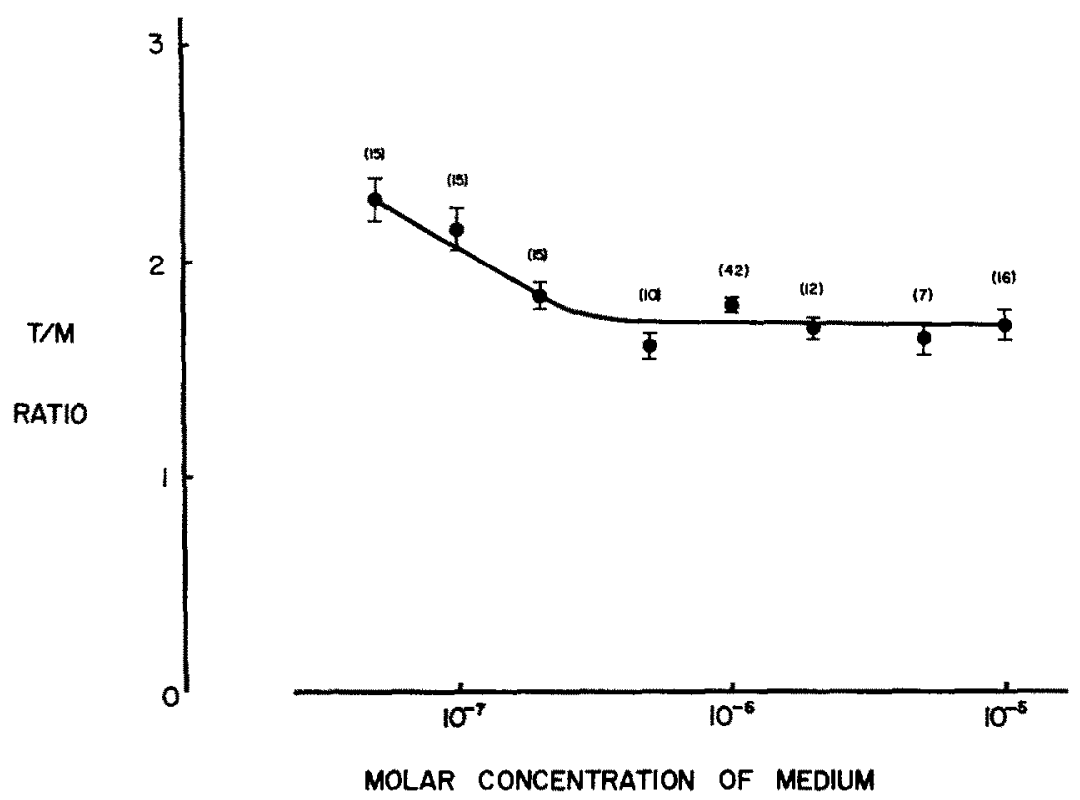

FIG. 2. Effect of the concentration of dihydromorphine in medium on its uptake by cerebral cortical slices. Slices prepared from rats were incubated for $10 \mathrm{~min}$ with different concentrations of the drug in the medium. Conditions of incubation and graphic representation were as described for Fig. 1 .

Above this concentration, the $T / M$ ratio was fairly constant around a ratio of $1 \cdot 7$, suggesting a nonsaturable component in the total uptake. The apparent $K_{\mathrm{m}}$ for the total uptake process was determined to be approximately $2 \times 10^{-6} \mathrm{M}$ with an apparent $V_{\max }$ of $21 \mathrm{n}-\mathrm{mole} / \mathrm{g}$ tissue $/ \mathrm{hr}$. At $0^{\circ}$ the $\mathrm{T} / \mathrm{M}$ was constant at 0.5 to 0.6 after $10 \mathrm{~min}$ of incubation for all concentrations studied $\left(5 \times 10^{-7}\right.$ to $\left.1 \times 10^{-4} \mathrm{M}\right)$.

The steady state accumulation of dihydromorphine by cerebral cortical tissue was dependent on aerobic metabolism (Table 2). It may be noted that significant depression of uptake occurred when glucose was omitted from the medium or when a nitrogen atmosphere was employed. Neither of these methods of inhibition would be expected to alter simple diffusion and physicochemical binding of dihydromorphine to tissue components.

The inhibitor of active transport ATPase, ouabain, ${ }^{15}$ reduced the steady state accumulation of dihydromorphine (Table 2). Ouabain $\left(1 \times 10^{-4} \mathrm{M}\right)$ also depressed the initial rate of uptake (measured at $10 \mathrm{~min})$ by $15.8 \pm 4.2$ per cent $(n=7$; $\mathbf{P}<0.001$ ). 
TABLE 2. EFFECT OF METABOLIC INHIBITORS ON THE STEADY STATE ACCUMULATION OF DIHYDROMORPHINE BY RAT CEREBRAL CORTICAL SLICES*

\begin{tabular}{|c|c|c|c|c|}
\hline Inhibitor & $\begin{array}{l}\text { Concn } \\
\text { (M) }\end{array}$ & $\mathrm{n}$ & $\begin{array}{l}\% \text { of Control } \dagger \\
( \pm \text { S.E.M. })\end{array}$ & $P$ value \\
\hline $\begin{array}{l}\text { Dinitrophenol } \\
\text { Iodoacetate } \\
\text { Glucose omitted } \\
\text { Nitrogen atmosphere } \\
\text { Ouabain } \\
\text { Ouabain } \\
\text { Temperature }\left(0^{\circ}\right)\end{array}$ & $\begin{array}{l}1 \times 10^{-3} \\
2 \times 10^{-4}\end{array}$ & $\begin{array}{l}3 \\
6 \\
3 \\
6 \\
5 \\
3 \\
4\end{array}$ & $\begin{array}{l}71 \pm 3 \\
71 \pm 6 \\
79 \pm 4 \\
75 \pm 1 \\
86 \pm 10 \\
71 \pm 1 \\
50 \pm 5\end{array}$ & $\begin{array}{l}<0.02 \\
<0.01 \\
<0.05 \\
<0.001 \\
\text { NS } \\
<0.01 \\
<0.01\end{array}$ \\
\hline
\end{tabular}

* Tissues were preincubated $15 \mathrm{~min}$ with or without the inhibitor and then incubated with $1 \times 10^{-6} \mathrm{M}$ dihydromorphine in the presence or absence of the inhibitor for $60 \mathrm{~min}$ at $37^{\circ}$ under an atmosphere of $\mathrm{O}_{2}: \mathrm{CO}_{2}(95: 5)$ except as noted. The number of animals is indicated by n, and each animal served as its own control. NS $=$ not significant.

$\uparrow$ The mean control T/M was $2 \cdot 0 \pm 0 \cdot 1$ (S.E.M.) for all 18 animals used in these experiments.

The influence of $\mathrm{pH}$ on the uptake of dihydromorphine is illustrated in Fig. 3. Increased uptake occurred with decreased hydrogen ion concentration of the medium. A maximum $\mathrm{T} / \mathrm{M}$ ratio of $3.6 \pm 0.2$ was reached at $\mathrm{pH} 8.2$; above this $\mathrm{pH}$ the $\mathrm{T} / \mathrm{M}$ declined. However, it is not possible with these data to state whether the decreased

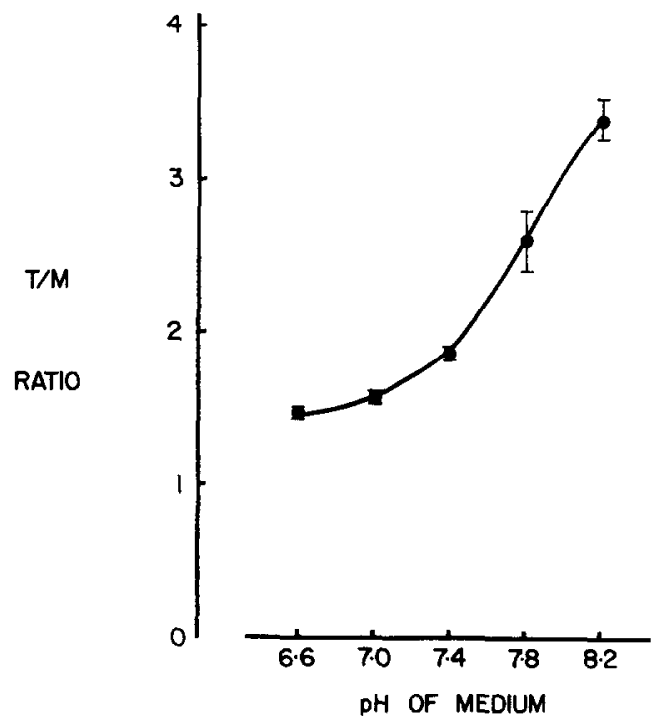

FIG. 3. Effect of $\mathrm{pH}$ of the medium on the steady state accumulation ( $60 \mathrm{~min}$ at $\left.37^{\circ}\right)$ of dihydromorphine $\left(1 \times 10^{-6} \mathrm{M}\right)$ by cerebral cortical slices taken from 4 rats. The $\mathrm{pH}$ was altered by varying the concentration of $\mathrm{NaHCO}_{3}$ and $\mathrm{NaCl}$ while maintaining a constant sodium ion concentration in the medium under an atmosphere of $\mathrm{O}_{2}: \mathrm{CO}_{2}(95: 5)$.

uptake at higher $\mathrm{pH}$ values was due to a true $\mathrm{pH}$ effect or to the higher sodium ion concentrations which occurred with the use of $\mathrm{NaHCO}_{3}$ in place of $\mathrm{NaCl}$ to produce a $\mathrm{pH}$ of 8.6 (i.e. $230 \mathrm{mEquiv} / \mathrm{l}$. $\mathrm{Na}$ ion vs. $155 \mathrm{mEquiv} / \mathrm{l}$. used routinely).

Dihydromorphine $\left(\mathrm{p} K_{\mathrm{a}} 8 \cdot 55\right)^{16}$ is approximately 93 per cent ionized as an organic base at $\mathrm{pH} 7 \cdot 4$. Quaternary organic bases are known to compete with narcotic 
analgesics for transport in both the kidney ${ }^{1-3}$ and choroid plexus. ${ }^{2}$ However, none of the quaternary bases (all used at a concentration of $10^{-3} \mathrm{M}$ ) appeared to affect the uptake of dihydromorphine into brain slices (Table 3). Note, however, that the uptake was depressed by the two morphine derivatives, codeine and nalorphine.

TABLE 3. EFFECT OF QUATERNARY ORGANIC BASES AND OF MORPHINE DERIVATIVES ON THE ACCUMULATION OF DIHYDROMORPHINE BY RAT CEREBRAL CORTICAL SLICES*

\begin{tabular}{lcccl}
\hline \multicolumn{1}{c}{ Compound } & $\begin{array}{c}\text { Concn } \\
(\mathbf{M})\end{array}$ & $\mathrm{n}$ & $\begin{array}{c}\% \text { of Control } \dagger \\
( \pm \text { S.E.M. })\end{array}$ & P value \\
\hline Quaternary organic bases & $1 \times 10^{-3}$ & 4 & $105 \pm 14$ & NS \\
$\quad$ Carbachol & $1 \times 10^{-3}$ & 4 & $112 \pm 11$ & NS \\
Choline & $1 \times 10^{-3}$ & 9 & $99 \pm 5$ & NS \\
$\begin{array}{l}\text { Decamethonium } \\
\text { Hexamethonium }\end{array}$ & $1 \times 10^{-3}$ & 12 & $95 \pm 5$ & NS \\
$\begin{array}{l}\text { Mepiperphenidol } \\
\text { Morphine derivatives }\end{array} \quad 1 \times 10^{-3}$ & 4 & $111 \pm 4$ & NS \\
$\quad$ Codeine & $1 \times 10^{-3}$ & 4 & $89 \pm 3$ & $<0.05$ \\
Nalorphinc & $1 \times 10^{-3}$ & 18 & $86 \pm 2$ & $<0.001$ \\
\hline
\end{tabular}

* Tissues were incubated for 10 min with $1 \times 10^{-6} \mathrm{M}$ dihydromorphine in the presence and absence of the compounds listed. Each animal (n) served as its own control. NS = not significant.

$\dagger$ The mean control $T / M$ was $1.8 \pm 0.1$ (S.E.M.) for all 26 animals used in these experiments.

The narcotic analgesic antagonist, nalorphine, consistently depressed the uptake of dihydromorphine by cerebral cortical slices. When the data were plotted according to the method of Lineweaver and Burk, ${ }^{17}$ the inhibition appeared to be competitive in nature (Fig. 4).

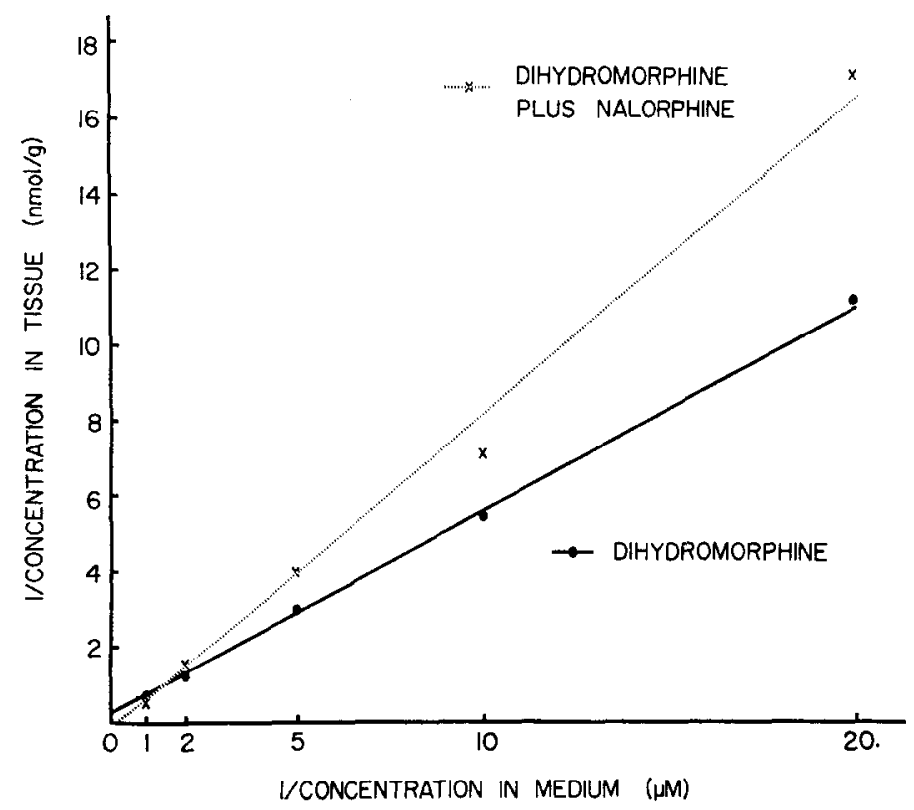

FIG. 4. Effect of nalorphine $\left(1 \times 10^{-3} \mathrm{M}\right)$ on the accumulation of dihydromorphine by cerebral cortical slices. The slices were prepared from rats and were incubated for $10 \mathrm{~min}$ at $37^{\circ}$ in media containing different concentrations of dihydromorphine $\left(0.05\right.$ to $\left.1.0 \times 10^{-6} \mathrm{M}\right)$. In the LineweaverBurk plot, each point is the mean value for 8 animals and the lines are fitted by the linear regression method. 
Uptake of other narcotic analgesics. All morphine and morphinan derivatives studied thus far (Table 4) were found to be accumulated in brain by a metabolically dependent process. In general, the relative total uptake of the compounds appeared to correlate with their degree of lipid solubility.

At a concentration of $5 \times 10^{-6} \mathrm{M}$, there was little difference between the uptake of the stereoisomers, as can be seen in Table 4. However, at lower concentrations the levo-isomer, levorphan, was accumulated more rapidly than the corresponding dextrorotatary compound, dextrorphan.

Table 4. Metabolically DEPENDENT UPTake OF MORPhine DERIVATIVES AND MORPHINAN DERIVATIVES BY RAT CEREBRAL CORTICAL SLICES*

\begin{tabular}{|c|c|c|c|}
\hline \multirow{2}{*}{ Compound } & \multirow{2}{*}{ D.R. $\dagger$} & \multicolumn{2}{|c|}{$\mathrm{T} / \mathrm{M}$ ratio \pm S.E.M. } \\
\hline & & $37^{\circ}$ & $0^{\circ}$ \\
\hline Dihydromorphine & 1.0 & $1 \cdot 6 \pm 0 \cdot 1$ & $0.52 \pm 0.05$ \\
\hline Morphine & 1.5 & $2 \cdot 1 \pm 0 \cdot 1$ & $0.89 \pm 0.09$ \\
\hline Nalorphine & 1.8 & $2.9 \pm 0.3$ & $1.08 \pm 0.10$ \\
\hline Levophan & $3 \cdot 1$ & $5.7 \pm 1.0$ & $1.46 \pm 0.21$ \\
\hline Dextrorphan & $3 \cdot 0$ & $5.5 \pm 0.4$ & $1.22 \pm 0.06$ \\
\hline Codeine & & $7.0 \pm 0.8$ & $2.53 \pm 0.42$ \\
\hline l-Methorphan & $7 \cdot 4$ & $8.7 \pm 0.8$ & $2 \cdot 07 \pm 0 \cdot 11$ \\
\hline$d$-Methorphan & $7 \cdot 4$ & $7.6 \pm 0.8$ & $2 \cdot 16 \pm 0.18$ \\
\hline
\end{tabular}

* Tissues were incubated for $10 \mathrm{~min}$ with the radioactive narcotic analgesic $\left(5 \times 10^{-6} \mathrm{M}\right)$. Tissues from 4 animals were used for each compound and each animal served as its own control.

$\uparrow$ Solvent-water distribution ratios (D.R.) were determined for ethylene dichloride and an equal volume of $0.2 \mathrm{M}$ aqueous potassium phosphate at $\mathrm{pH} \mathrm{7.4}$. The values are relative to that of dihydromorphine, which is arbitrarily designated as 1.0 (L. B. Mellett, personal communication):

Uptake of dihydromorphine by cerebral cortical slices from different species. In all other species studied, including the monkey, mouse and rabbit, the uptake of dihydromorphine was found to be metabolically dependent (Table 5).

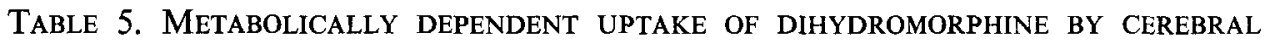
CORTICAL SLICES OF VARIOUS ANIMAL SPECIES*

\begin{tabular}{|c|c|c|c|}
\hline \multirow{2}{*}{ Species } & \multicolumn{3}{|c|}{$\mathrm{T} / \mathbf{M}$ ratio \pm S.E.M. } \\
\hline & Control & $\mathrm{N}_{2}$ atmosphere & $\begin{array}{c}\text { Temperature } \\
\left(0^{\circ}\right)\end{array}$ \\
\hline $\begin{array}{l}\text { Monkey } \\
\text { Rabbit } \\
\text { Rat } \\
\text { Mouse }\end{array}$ & $\begin{array}{l}2 \cdot 1 \quad(1) \\
1 \cdot 6 \pm 0 \cdot 1(10) \\
2 \cdot 1 \pm 0 \cdot 1(35) \\
2 \cdot 2 \pm 0 \cdot 1(5)\end{array}$ & $\begin{array}{l}1.5 \quad(1) \\
1.4 \pm 0.1(3) \\
1.6 \pm 0.1(6) \\
1.4 \pm 0.1(6)\end{array}$ & $\begin{array}{l}0.99 \\
0.85 \pm 0.05(3) \\
0.95 \pm 0.06(8)\end{array}$ \\
\hline
\end{tabular}

* Tissues were incubated for $60 \mathrm{~min}$ with $1 \times 10^{-6} \mathrm{M}$ dihydromorphine at $37^{\circ}$ or $0^{\circ}$ under an atmosphere of $\mathrm{O}_{2}: \mathrm{CO}_{2}(95: 5)$ or $\mathrm{N}_{2}: \mathrm{CO}_{2}(95: 5)$. The number of animals used for each value is indicated in parentheses.

\section{DISCUSSION}

Narcotic analgesics have been shown to be taken up into brain slices by a process having many of the characteristics of active transport, including uptake against an 
apparent concentration gradient, saturability, metabolic dependence, structural specificity, stereospecificity and substrate competition.

A nonsaturable component was also observed in the accumulation of narcotic analgesics in cortical slices, as evidenced by a constant $T / M$ ratio of about 1.7 above a concentration of $5 \times 10^{-6} \mathrm{M}$ in the medium. The relative contribution of simple diffusion and a binding process with a high capacity cannot be distinguished by these experiments.

The results discussed above are in disagreement with those obtained by Bell18 and by Miller and Elliott, ${ }^{19}$ who could not reduce uptake of morphine and methadone, respectively, by metabolic inhibition, by omission of glucose from the medium or by the addition of nalorphine. Although methadone was not included in our studies, it might be predicted that transport would be observed only at low concentrations of these drugs, and that at the higher concentrations of drug used by these investigators (i.e. $0 \cdot 1$ to $1 \mathrm{mM}$ ) only binding and diffusion contributed significantly to the total uptake.

In comparison to results obtained in the kidney and choroid plexus, 2,4 the system transporting the narcotic analgesics into brain slices was found to have a lower capacity for uptake of dihydromorphine, as evidenced by the low T/M ratio at equilibrium.

In addition, unlike the earlier studies with the kidney and choroid plexus, quaternary organic bases did not appear to compete with dihydromorphine for uptake into brain slices. These results with brain slices were not unexpected, since Tochino and Schan$\mathrm{ker}^{20}$ found no evidence for transport of the organic base, hexamethonium, into brain slices against a concentration gradient.

On the other hand, the accumulation of choline into brain slices as reported by Schuberth $e$ e $a .^{21}$ and of carbachol as reported by Creese and Taylor ${ }^{22}$ may be due to uptake by a system other than that transporting the narcotic analgesics.

The effects of some tertiary and secondary bases on dihydromorphine uptake are currently being studied. Preliminary results by Oka and Hug (unpublished) suggest that histamine, norepinephrine and serotonin all inhibit dihydromorphine uptake into brain slices. Investigation is continuing in our laboratory to determine if narcotic analgesics are transported by one of the systems normally operating to accumulate these or other constituents of brain tissue.

Codeine, an analgesic, and nalorphine, an analgesic antagonist with analgesic action, ${ }^{23}$ both depressed the uptake of dihydromorphine by brain slices. The inhibition of uptake by nalorphine was shown to be a competitive one. Such depression may represent competition for transport or tissue binding sites or for both, competition which is to be expected for such structurally similar analogues, which are also accumulated by the slices.

Finally, it should be emphasized that demonstration of active transport in tissue slices provides no indication of the direction of the transport in the intact animal (e.g. blood to brain vs. brain to blood). However, since many of the narcotic analgesics enter the central nervous system to a very limited degree, ${ }^{24-26}$ it is tempting to speculate that the transport mechanism demonstrated in vitro may function to limit the penetration of these drugs into brain. ${ }^{6}$

Acknowledgements - The technical assistance of Louis Harrel in the analysis of the narcotic analgesics is gratefully acknowledged. 


\section{REFERENCES}

1. C. C. Hug, JR., L. B. Mellett and E. J. CAfruny, J. Pharmac. exp. Ther. 150, 259 (1965).

2. C. C. Hug, JR., Biochem. Pharmac. 16, 345 (1967).

3. D. G. MAY, J. M. Fujimoto and C. E. INTURRISI, J. Pharmac, exp. Ther. 157, 626 (1967).

4. A. E. TAKEMORI and M. W. STenwick, J. Pharmac. exp. Ther. 154, 586 (1966).

5. D. P. Rall and C. G. Zubrod, A. Rev. Pharmac. 2, 109 (1962).

6. R. EDSTRÖM, Int. Rev. Neurobiol. 7, 153 (1964).

7. J. H. Quastel, Can. J. Biochem. Physiol. 42, 907 (1964).

8. H. McIlwain and R. Rodnight, Practical Neurochemistry. Little, Brown, Boston (1962).

9. Liquid Scintillation Counting, Nuclear-Chicago Publication No. 711580, 2nd edn (1966).

10. G. J. Mannering, A. C. Dixon, N. V. Carroll and O. B. Cope, J. Lab. clin. Med. 44, 292 (1954).

11. C. C. Hug, JR. and L. B. Mellett, Univ. Mich. med. Bull. 29, 165 (1963).

12. L. B. Mellet, The Pharmacologist 5, 251 (1963).

13. C. C. Hug, JR. and L. A. Woods, J. Pharmac. exp. Ther. 142, 248 (1963).

14. H. McIlwain, Biochemistry and the Central Nervous System, 3rd edn. Little, Brown, Boston (1966).

15. J. C. SKou, Physiol. Rev. 45, 596 (1965).

16. L. Levi, P. M. Oestreicher and C. G. Farmilo, Bull. Narcot. 5, 15 (1953).

17. H. LINEWEAVER and D. BURK, $J$. Am. chem. Soc. 56, 658 (1934).

18. J. L. BeLl, J. Neurochem. 2, 265 (1958).

19. J. W. Miller and H. W. Elliott, J. Pharmac. exp. Ther. 110, 106 (1954).

20. Y. Tochino and L. S. SChanker, Am. J. Physiol. 208, 666 (1965).

21. J. SChumerth, A. Sundwall, B. Sörbo and J-O. Lindell, J. Neurochem. 13, 347 (1966).

22. R. Creese and D. B. TAYlor, J. Pharmac. exp. Ther. 157, 406 (1967).

23. L. LASAgna and H. K. Beecher, J. Pharmac. exp. Ther. 112, 356. (1954).

24. E. L. WAY and T. K. AdLer, The Biological Disposition of Morphine and its Surrogates. World Health Org., Geneva (1962).

25. C. C. HUG, $\mathrm{J}_{\mathrm{R}}$, Tritium-Labeled Dihydromorphine (Doctoral dissertation) University of Michigan (1963)

26. S. J. Mulé and L. A. Woods, J. Pharmac. exp. Ther. 136, 232 (1962). 